\title{
Prevalence of Vibrio parahaemolyticus in seabass (Dicentrarchus Labrax) and seabream (Sparus aurata) and Detection of Streptomycin-resistant Strains
}

\author{
Adel M. El-Gamal ${ }^{1 *}$ and Engy F. EL-Bahi ${ }^{2}$ \\ ${ }^{1}$ Bacteriology unit. Animal Health Research Institute, Kafr El-Sheikh branch, Agriculture research center (ARC), Egypt. \\ ${ }^{2}$ Food hygiene unit. Animal Health Research Institute, Kafr El-Sheikh branch, Agriculture research center (ARC), Egypt. \\ *Corresponding author's Email: adelelgamal5544@yahoo.com; (D) ORCiD: 0000-0002-7697-929X
}

\begin{abstract}
Vibrio species are the most common and serious pathogens in fish and shellfish marine aquaculture worldwide. The present study aimed to determine the prevalence of Vibrio spp. in seabass and seabream in fish markets, especially streptomycin-resistant strains that have great public health importance. A total of 30 seabass (Dicentrarchus Labrax) and 30 seabream (Sparus aurata) were purchased from fish markets at Kafr El Sheikh Governorate and subjected to bacteriological examination. The PCR assay was used for the detection of virulence genes ( $t d h$ and $t r h$ ), aminoglycoside resistance gene (aadA1), and toxR gene. The results indicated that the total prevalence of Vibrio spp. was $26.66 \%$, including $V$. parahaemolyticus $(8.3 \%)$, V. alginolyticus $(8.3 \%), V$. mimicus $(3.3 \%)$, V. harveyi $(5 \%)$ and $V$. vulnificus (1.6\%). The toxR, trh, and aadAl genes were found in all $V$. parahaemolyticus isolates while $t d h$ gene was found in $80 \%$ of isolates. Antimicrobial sensitivity test of $V$. parahaemolyticus isolates showed sensitivity to ciprofloxacin, norfloxacin, cefotaxime, and chloramphenicol. Vibrio parahaemolyticus isolates were resistant to ampicillin, erythromycin, streptomycin, and gentamycin. The present results indicated that good hygienic measures should be taken to avoid infection with Vibrio species, especially $V$. parahaemolyticus that can pose a great risk to human health.
\end{abstract}

Keywords: Antibiotic resistance, Seabass, Seabream, Streptomycin, Vibrio parahaemolyticus.

\section{INTRODUCTION}

Vibrio genus contains Gram-negative, halophilic, rod-shaped, non-spore forming, oxidase-positive bacteria, which widespread in the coastal and estuarine environments (Austin and Austin, 2007). Vibrio parahaemolyticus is the most recorded pathogenic species of Vibrio genus and affects persons who consume improperly cooked or raw seafood (Raissy et al., 2015). This foodborne bacteria is reported as the main cause of seafood-borne illness in Egypt and many other countries around the world such as United States, Malaysia, Thailand, Korea, China, and Japan (Yoon et al., 2008; Iwahori et al., 2010; Abdel-Azeem et al., 2016). Infection with $V$. parahaemolyticus may cause acute human gastroenteritis, the major symptoms of which are headache, diarrhea, abdominal pain, and in some cases, septicemia (Broberg et al., 2011; Wang et al., 2015; Su and Liu, 2017). In coastal areas of the world, like Japan, $V$. parahaemolyticus has been regularly recognized as the main cause of sporadic cases of gastroenteritis (Qadri et al., 2005; Wang et al., 2017). In China, about 322 gastroenteritis outbreaks due to $V$. parahaemolyticus infection were reported from 2003 to 2008 (Wu et al., 2014). Multiplication of V. parahaemolyticus is related to water temperature and season (Deepanjali et al., 2005; Angela et al., 2006), with the highest prevalence in summer due to the higher salinity of water than other seasons (Zulkifli et al., 2009).

The pathogenicity of bacteria depends mainly on some virulence factors and virulence genes, which act together as major orchestrators. The most virulence genes leading to pathogenicity of $V$. parahaemolyticus are hemolysin genes (tdh and $t r h$ ) (Hiyoshi et al., 2010). Molecular epidemiological studies demonstrated a clear relation between the hemolysin genes and disease-causing ability of V. parahaemolyticus (Kishishita et al., 1992; DePaola et al., 2003; Vongxay et al., 2008; Chao et al., 2009; Han et al., 2015; Hasrimi et al., 2018). These two genes were recorded in the most isolates from clinical cases of $V$. parahaemolyticus infections (Bej et al., 1999; Rojas et al., 2011). The $t d h$ and $t r h$ genes encode virulence factors of thermostable direct hemolysin (TDH), and TDH-related hemolysin (TRH), respectively, which are involved in important pathogenic activities, such as enterotoxicity, hemolytic activity, cytotoxicity and cardiotoxicity (Shirai et al., 1990; Osawa et al., 1996).

The toxR gene is a pandemic marker gene for all V. parahaemolyticus strains either pathogenic or nonpathogenic one, and it was recorded in some other Vibrio species (Kim et al., 1999). The sequence of toxR gene can be used for molecular identification of V. parahaemolyticus (Yung et al., 1999; Hubbard et al., 2016). The aadAl and aadA2 encode 
aminoglycoside adenyl transferase and confer resistance to streptomycin, already are detected in Vibrio species isolates (Dalsgaard et al., 2001).

Cooking and frying of marine fish reduce the count of $V$. parahaemolyticus. After cooking (in oven $120^{\circ} \mathrm{C}$ for 35 $\mathrm{min}$ ), the percentage reduction in total count of V. parahaemolyticus was $98.2 \%$, while after frying for $10 \mathrm{~min}$ at $190{ }^{\circ} \mathrm{C}$, $V$. parahaemolyticus was completely destroyed and the percentage reduction was $100 \%$ (Saad et al., 2015); or even boiling at $64^{\circ} \mathrm{C}$ for more than 90 seconds can kill $V$. parahaemolyticus (ICMSF, 1996). The bacteria will be removed by using high cooking temperature, although the toxin might remain in the foodstuff depending on the processing conditions (Raissy et al., 2015). The current study aimed to determine the prevalence of Vibrio spp., especially streptomycinresistant strains, in seabass and seabream in fish markets of Kafr El Sheikh Governorate, Egypt.

\section{MATERIALS AND METHODS}

\section{Samples collection}

Thirty seabass and 30 seabream with a weight range of 100-250 g were purchased from fish markets at Kafr El Sheikh Governorate from February to August 2019. All samples were transferred in ice box to Animal Health Research Institute, Kafr El Sheikh laboratory, Egypt.

\section{Bacteriological examination}

Bacteriological examinations were done according to ISO/ TS 21872-1 (2007) and ISO/ TS 21872-2 (2007).

\section{Samples preparation}

After skin sterilization with alcohol, the muscles above the lateral line were removed, $25 \mathrm{~g}$ of each fish sample were mixed with $225 \mathrm{ml}$ of alkaline saline peptone water (APW, pH 8.6) in a Stomacher bag. After that, these mixtures were incubated at $37{ }^{\circ} \mathrm{C}$ for $8-16$ hours.

\section{Isolation of Vibrio species}

After the incubation period, the upper layer of the alkaline saline peptone water (APW) enrichment broth was inculcated on Thiosulfate-citrate-bile salts-sucrose (TCBS) agar (Oxoid, UK), and then these plates were incubated at 37 ${ }^{\circ} \mathrm{C}$ for another 18-24 hours. After that, growing colonies were used for further screening tests including Gram staining, oxidase and catalase tests.

\section{Biochemical identification}

Suspected colonies of Vibrio spp. on TCBS media and positive oxidase test were subjected to further identification by Microbact GNB kit (Oxoid, UK).

\section{Polymerase chain action}

Suspected isolates of the $V$. parahaemolyticus were examined by using PCR for the detection of virulence genes (tdh and trh), toxR gene, and aadAl gene. DNA extraction were performed according to the manufacturer's recommendations by using the QIA amp DNA Mini kit (Qiagene, Germany, GmbH). Oligonucleotide primers were supplied from Metabion (Germany). The primers were utilized in a 25- $\mu 1$ reaction containing $12.5 \mu 1$ of Emerald Amp Max PCR Master Mix (Takara, Japan) using an Applied Biosystem 2720 thermal cycler. Primers used and PCR conditions are presented in Table 1. The products of PCR were separated by electrophoresis on 1\% Agarose gel (Applichem, Germany, GmbH) in 1x TBE buffer at room temperature using gradients of $5 \mathrm{~V} / \mathrm{cm}$. The gel was photographed by a gel documentation system (Alpha Innotech, Biometra).

\section{Antimicrobial susceptibility test}

Antimicrobial disk susceptibility test were performed as described by the Clinical and Laboratory Standards Institute (CLSI, 2012).

Table 1. Primers sequences, target genes, amplicon sizes and cycling conditions.

\begin{tabular}{|c|c|c|c|c|c|c|c|c|c|}
\hline \multirow{2}{*}{$\begin{array}{l}\text { Target } \\
\text { genes }\end{array}$} & \multirow{2}{*}{\multicolumn{2}{|c|}{ Primers Sequence (5'-3') }} & \multirow{2}{*}{$\begin{array}{c}\text { Amplified } \\
\text { segment } \\
\text { (base pair) }\end{array}$} & \multirow{2}{*}{$\begin{array}{c}\text { Primary } \\
\text { denaturat } \\
\text { ion }\end{array}$} & \multicolumn{3}{|c|}{ Amplification ( 35 cycles) } & \multirow{2}{*}{$\begin{array}{c}\text { Final } \\
\text { extension }\end{array}$} & \multirow{2}{*}{ Reference } \\
\hline & & & & & $\begin{array}{c}\text { Secondary } \\
\text { denaturation }\end{array}$ & $\begin{array}{c}\text { Annealin } \\
\mathrm{g}\end{array}$ & $\begin{array}{c}\text { Extensi } \\
\text { on }\end{array}$ & & \\
\hline \multirow{2}{*}{$\operatorname{tox} R$} & $\mathrm{~F}$ & GTCTTCTGACGCAATCGTTG & \multirow{2}{*}{368} & \multirow{2}{*}{$\begin{array}{l}94^{\circ} \mathrm{C} \\
5 \mathrm{~min} .\end{array}$} & \multirow{2}{*}{$\begin{array}{c}94^{\circ} \mathrm{C} \\
30 \mathrm{sec} .\end{array}$} & \multirow{2}{*}{$\begin{array}{c}55^{\circ} \mathrm{C} \\
40 \mathrm{sec} .\end{array}$} & \multirow{2}{*}{$\begin{array}{l}72^{\circ} \mathrm{C} \\
40 \mathrm{sec} .\end{array}$} & \multirow{2}{*}{$\begin{array}{c}72^{\circ} \mathrm{C} \\
10 \mathrm{~min} .\end{array}$} & \multirow{2}{*}{$\begin{array}{c}\text { Kim et al., } \\
1999\end{array}$} \\
\hline & $\mathrm{R}$ & ATACGAGTGGTTGCTGTCATG & & & & & & & \\
\hline \multirow{2}{*}{ aadAl } & $\mathrm{F}$ & TATCAGAGGTAGTTGGCGTCAT & \multirow{2}{*}{484} & \multirow{2}{*}{$\begin{array}{l}94^{\circ} \mathrm{C} \\
5 \mathrm{~min} .\end{array}$} & \multirow{2}{*}{$\begin{array}{c}94^{\circ} \mathrm{C} \\
30 \mathrm{sec}\end{array}$} & \multirow{2}{*}{$\begin{array}{c}54^{\circ} \mathrm{C} \\
40 \mathrm{sec} .\end{array}$} & \multirow{2}{*}{$\begin{array}{l}72^{\circ} \mathrm{C} \\
45 \mathrm{sec}\end{array}$} & \multirow{2}{*}{$\begin{array}{c}72^{\circ} \mathrm{C} \\
10 \mathrm{~min} .\end{array}$} & \multirow{2}{*}{$\begin{array}{l}\text { Randall et } \\
\text { al. } 2004\end{array}$} \\
\hline & $\mathrm{R}$ & GTTCCATAGCGTTAAGGTTTCATT & & & & & & & \\
\hline \multirow{2}{*}{$\operatorname{trh}$} & $\mathrm{F}$ & GGCTCAAAATGGTTAAGCG & \multirow{2}{*}{250} & \multirow{2}{*}{$\begin{array}{l}94^{\circ} \mathrm{C} \\
5 \mathrm{~min} .\end{array}$} & \multirow{2}{*}{$\begin{array}{c}94^{\circ} \mathrm{C} \\
30 \mathrm{sec} .\end{array}$} & \multirow{2}{*}{$\begin{array}{c}54^{\circ} \mathrm{C} \\
30 \mathrm{sec} .\end{array}$} & \multirow{2}{*}{$\begin{array}{c}72^{\circ} \mathrm{C} \\
30 \mathrm{sec}\end{array}$} & \multirow{2}{*}{$\begin{array}{l}72^{\circ} \mathrm{C} \\
7 \mathrm{~min} .\end{array}$} & \multirow{4}{*}{$\begin{array}{c}\text { Mustapha et } \\
\text { al., } 2013\end{array}$} \\
\hline & $\mathrm{R}$ & CATTTCCGCTCTCATATGC & & & & & & & \\
\hline \multirow{2}{*}{$t d h$} & $\mathrm{~F}$ & CCATCTGTCCCTTTTCCTGC & \multirow{2}{*}{373} & \multirow{2}{*}{$\begin{array}{l}94^{\circ} \mathrm{C} \\
5 \mathrm{~min} .\end{array}$} & \multirow{2}{*}{$\begin{array}{c}94^{\circ} \mathrm{C} \\
30 \mathrm{sec} .\end{array}$} & \multirow{2}{*}{$\begin{array}{c}54^{\circ} \mathrm{C} \\
30 \mathrm{sec} .\end{array}$} & \multirow{2}{*}{$\begin{array}{l}72^{\circ} \mathrm{C} \\
40 \mathrm{sec}\end{array}$} & \multirow{2}{*}{$\begin{array}{l}72^{\circ} \mathrm{C} \\
7 \mathrm{~min}\end{array}$} & \\
\hline & $\mathrm{R}$ & CCAAATACATTTTACTTGG & & & & & & & \\
\hline
\end{tabular}


Vibrio spp. commonly inhabit the marine environments and can be found in the fresh water (Sujeewa et al., 2009). Seafood may be a vehicle for most of the bacterial pathogens such as Vibrio spp. (Huss, 1997). Various outbreaks of bacterial disease associated with seafood consumption have been reported (Friesema et al., 2012). Recently, $V$. parahaemolyticus recoded as an important species causing seafood infection associated with gastroenteritis illness in humans.

Table 2 shows that the total incidence of Vibrio spp. isolated from the examined seabass and seabream samples is $26.66 \%$ (16 out of 60 samples). Raissy et al. (2015) and Azwail et al. (2016) recorded nearly similar results (22\% and $22.9 \%$, respectively). however, the result of present study is lower than that recorded by Pal and Das (2010), Saad et al. (2015), Abdel-Azeem et al. (2016), Fri et al. (2017), and Hemmat et al. (2018). These differences may be due to difference in the type of examined fish, difference in the method of bacterial isolation, or difference in the hygienic state of fish sources. Additionally, the difference in results can be attributed to difference in season of sampling, as Vibrio spp. has been reported to have higher concentrations in summer seasons due to higher water salinity levels than other seasons (Zulkifli et al., 2009). As presented in table 2, several Vibrio strains were isolated from examined seabass and seabream, including V. parahaemolyticus (8.3\%), V. alginolyticus (8.3\%), V. mimicus (3.3\%), V. harveyi (5\%) and V. vulnificus $(1.6 \%)$. Vibrio cholera was not detected in the studied samples. The examined seabass fish were more infected with $V$. parahaemolyticus than the examined seabream fish which may be due to the hygienic state of each fish source.

Similarly, Saad et al. (2015) isolated V. parahaemolyticus (10\%), V. fluvialis, V. vulnificus, V. alginolyticus , V. mimicus, and V. damsel from Tilapia nilotica and Mugil Cephalus. Hemmat et al. (2018) isolated V. parahaemolyticus (12\%), V. mimicus, V. alginolyticus, V. cholera, V. vulnificus, and V. fluvialis from Oreochromis niloticus, Mugil Cephalus, shrimp and crab. Raissy et al. (2015) isolated $V$. harveyi that was the most frequent species isolated, followed by V.parahaemolyticus (3.5\%), V. mimicus, V. vulnificus, and V. alginolyticus from some marine fish and shrimps. Fri et al. (2017) isolated V. fluvialis, Vibrio vulnificus, and V. parahaemolyticus (5.45\%) from dusky kop fish and sea water. Pal and Das (2010) isolated Vibrio parahaemolyticus with a high prevalence (35\%) from shrimp, prawn, bhetki, pamfret and hilsa. According to the Egyptian Organization for Standardization and Quality Control (EOSQC, 2005), any seafood products must be free from $V$. parahaemolyticus.

As shown in table 3 and figure 1, all examined Vibrio parahaemolyticus isolates were positive for toxR gene. This result support finding of Yung et al. (1999); Pal and Das (2010), who reported that toxR-targeted PCR protocol can be used for V. parahaemolyticus detection. Also, all examined Vibrio parahaemolyticus isolates were positive for aadAl gene (Figure 2). Taviani et al. (2008) stated that aadAl gene is responsible for antibiotic resistance against aminoglycoside group including streptomycin in Vibrio spp. isolates from shellfish and other marine fish.

Pathogenicity of $V$. parahaemolyticus is conferred either by $t d h$, and/or trh (Yamaichi et al., 1999). As shown in table 3, all examined $V$. parahaemolyticus isolates were positive for $t r h$ gene (figure 3), and $80 \%$ were positive for $t d h$ gene (Figure 4). The results did not match with that reported by Rojas et al. (2011) who detected $t d h$ gene in $10.5 \%$ of $V$. parahaemolyticus isolates, while trh gene was not found. Also, Pal and Das (2010) recorded $t d h$ gene in $35 \%$ of $V$. parahaemolyticus isolated from fish samples while trh gene was found only in $1.7 \%$ of $V$. parahaemolyticus isolates. Wang et al. (2017) recorded the virulence genes; $t d h$ and $t r h$ with $87.9 \%$ and $3.7 \%$ of examined $V$. parahaemolyticus strains, respectively. Fri et al. (2017) recorded trh gene as $9.46 \%$ in examined V.parahaemolyticus strains, while Wong et al. (2000) recorded only one $V$. parahaemolyticus isolate (1.4\%) harboring trh gene, but did not detect $t d h$ gene among the examined $V$. parahaemolyticus isolates.

Antimicrobial susceptibility test showed that $V$. parahaemolyticus isolates were sensitive to ciprofloxacin, norfloxacin, cefotaxime, and chloramphenicol while they were resistant to ampicillin, erythromycin, streptomycin, and gentamycin (Table 4). These results indicate that the examined strains were resistant to most members of the aminoglycoside group, which may be due to the fact that aadAl gene was detected in all examined V. parahaemolyticus isolates. This result is nearly similar to that recorded by Rojas et al. (2011), who reported that V. parahaemolyticus had resistance to streptomycin and ampicillin with intermediate susceptibility to gentamicin.

Table 2. Prevalence of Vibrio species in examined seabass and seabream fish, Egypt.

\begin{tabular}{lccc}
\hline Vibrio spp. & \multicolumn{2}{c}{ Number of positive samples } \\
\cline { 2 - 4 } & $\begin{array}{c}\text { Seabass } \\
(\mathbf{n = 3 0 )}\end{array}$ & $\begin{array}{c}\text { Seabream } \\
(\mathbf{n = 3 0})\end{array}$ & Total (\%) \\
\hline V. parahaemolyticus & 1 & 4 & $5(8.3)$ \\
V. alginolyticus & 3 & 2 & $5(8.3)$ \\
V. mimicus & 0 & 2 & $2(3.3)$ \\
V. harveyi & 1 & 2 & $3(5)$ \\
V. vulnificus & 1 & 0 & $1(1.6)$ \\
Total & 6 & 10 & $16(26.6)$ \\
\hline
\end{tabular}


Table 3. Distribution of virulence genes among examined isolates of Vibrio parahaemolyticus isolated from seabass and seabream fish.

\begin{tabular}{|c|c|c|c|c|}
\hline Sample No. & toxR & $t d h$ & trh & $\operatorname{aadA1}$ \\
\hline 1 & + & + & + & + \\
\hline 2 & + & - & + & + \\
\hline 3 & + & + & + & + \\
\hline 4 & + & + & + & + \\
\hline 5 & + & + & + & + \\
\hline
\end{tabular}

Table 4. Results of agar disc diffusion test of Vibrio parahaemolyticus isolated from marine fish

\begin{tabular}{lcc}
\hline Antibiotic & Disc symbol \& concentration $(\boldsymbol{\mu g} / \mathbf{d i s c})$ & Result \\
\hline Norfloxacin & Nor $(10)$ & $\mathrm{S}$ \\
Erythromycin & $\mathrm{E}(15)$ & $\mathrm{R}$ \\
Ampicillin & $\mathrm{AMP}(10)$ & $\mathrm{R}$ \\
Amoxicillin + clavulinic acid & $\mathrm{AMC}(30)$ & $\mathrm{S}$ \\
Cefotaxime & $\mathrm{CTX}(30)$ & $\mathrm{S}$ \\
Doxycycline & $\mathrm{DO}(30)$ & $\mathrm{R}$ \\
Streptomycin & $\mathrm{S}(10)$ & $\mathrm{R}$ \\
Sulpamethazol + Trimethoprim & $\mathrm{SXT}(25)$ & $\mathrm{R}$ \\
Chloramphenicol & $\mathrm{C}(30)$ & $\mathrm{S}$ \\
Gentamycin & $\mathrm{CN}(10)$ & $\mathrm{R}$ \\
Ciprofloxacin & $\mathrm{Cip}(5)$ & $\mathrm{S}$ \\
\hline S. Sensitive R: Resistant & & \\
\hline
\end{tabular}

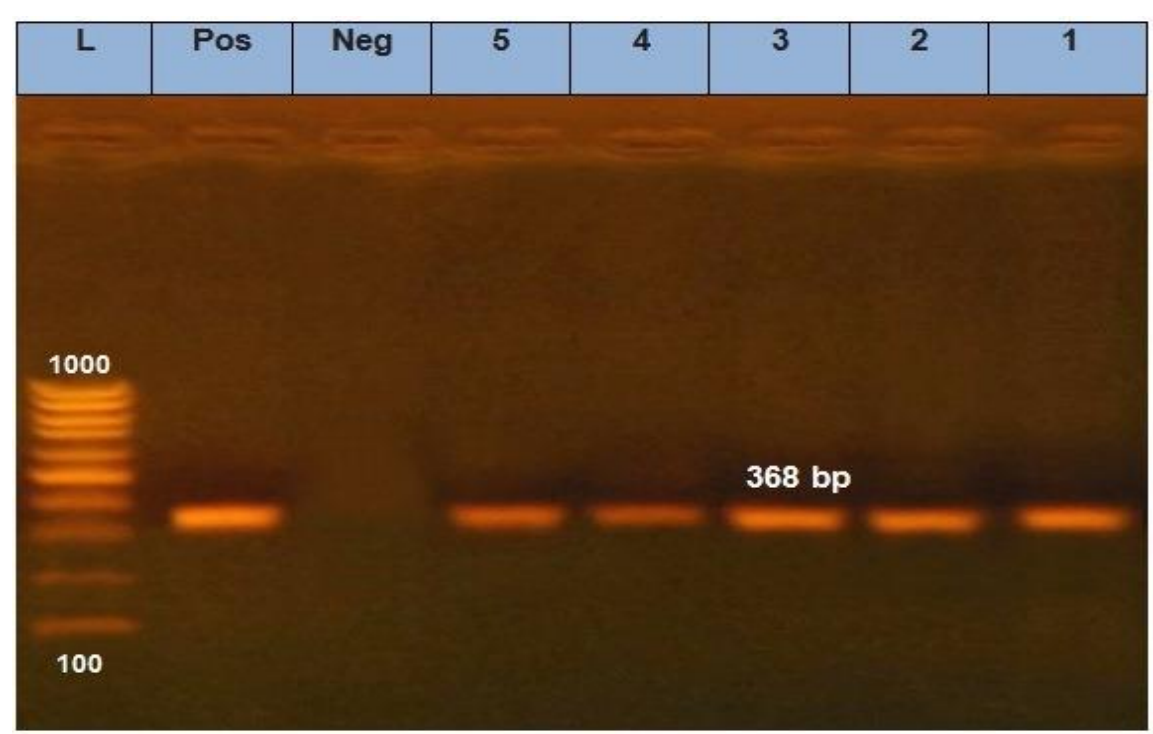

Figure 1. Agarose gel electrophoresis of PCR amplification of toxR gene (368 bp) of Vibrio parahaemolyticus. Lane L: 100-600 bp DNA Ladder. Neg.: Negative control. Pos.: Positive control. Lane 1-5: Positive samples.

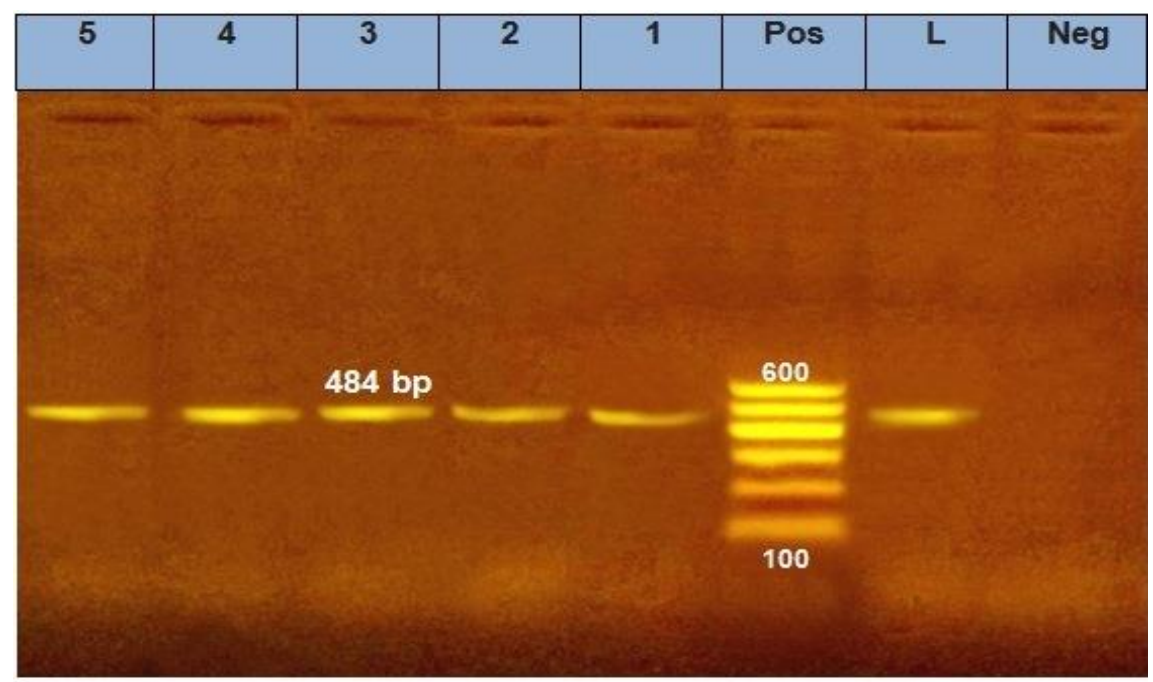

Figure 2. Agarose gel electrophoresis of PCR amplification of aadAl gene (484 bp) of Vibrio parahaemolyticus. Lane L: 100-600 bp DNA Ladder. Neg.: Negative control. Pos.: Positive control. Lane 1-5: Positive samples. 


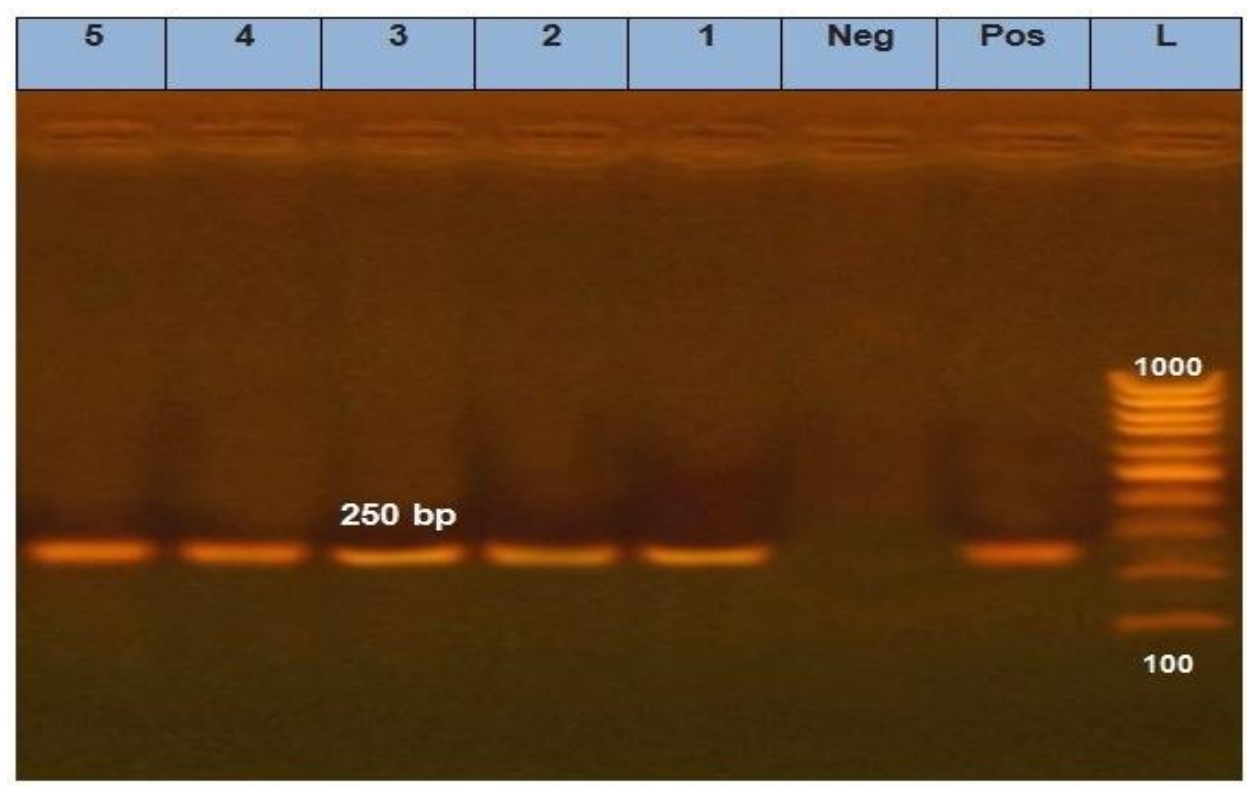

Figure 3. Agarose gel electrophoresis of PCR amplification of trh gene (250 bp) of Vibrio parahaemolyticus. Lane L: 100-600 bp DNA Ladder. Neg.: Negative control. Pos.: Positive control. Lane 1-5: Positive samples.

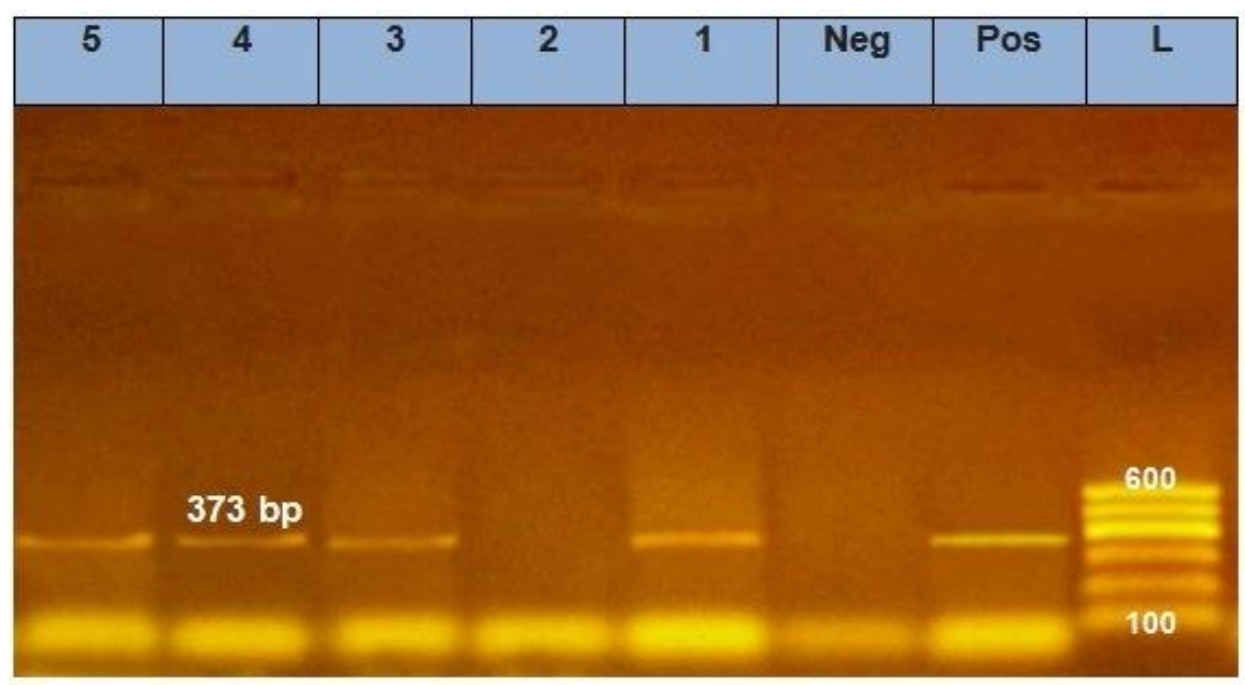

Figure 4. Agarose gel electrophoresis of PCR amplification of $t d h$ gene (373bp) of Vibrio parahaemolyticus. Lane L: 100-600 bp DNA Ladder. Neg.: Negative control. Pos.: Positive control. Lane 1,3,4 and 5: positive samples, Lane 2: negative sample.

\section{CONCLUSION}

Vibrio spp. especially $V$. parahaemolyticus, V. alginolyticus, V. mimicus, and V. vulnificus are commonly isolated from seabass and seabream fish, which affects persons who consume improperly cooked or raw seafood. Most of these bacteria have antibiotic resistance genes that pose a great risk to human health; therefore, good hygienic measures should apply to avoid such infections.

\section{DECLARATIONS}

\section{Acknowledgments}

The authors would like to thank all member of Animal Health Research Institute, Egypt, for their kindly help during the investigation and paper preparation.

\section{Authors' contributions}

All authors participated equally in study design, data collection, data analysis, writing, and approving the final manuscript.

\section{Competing interests}

The authors declare that they have no competing interests. 


\section{REFERENCES}

Angela D, Schulzea Abayomi O, Alabib Adele R, Sheldrakeb T and Miller KM (2006). Bacterial diversity in a marine hatchery: Balance between pathogeneic and potentially probiotic bacterial strains. Aquaculture, 256: 50-73. DOI: https://doi.org/10.1016/j.aquaculture.2006.02.008

Austin B and Austin DA (2007). Bacterial fish pathogens, disease of farmed and wild fish, 4th ed. Springer Praxis, Godalming. Available at: https://www.springer.com/gp/book/9781402060687

Azwai SM, Alfallani EA, Abolghait SK, Garbaj AM, Naas HT, Moawad AA, Gammoudi FT, Rayes HM, Barbieri I and Eldaghayes IM (2016). Isolation and molecular identification of Vibrio spp. by sequencing of 16S RNA from seafood, meat and meat products in Libya. Open Veterinary Journal, 6(1): 36-43. DOI: https://doi.org/10.4314/ovj.v6i1.6

Bej AK, Patterson DP, Brasher CW, Vickery MCL, Jones DD, and Kaysner CA (1999). Detection of total and hemolysin-producing Vibrio parahaemolyticus in shellfish using multiplex PCR amplification of $t h$, $t d h$, and $t r h$. Journal of Microbial Methods, $36: 215-225$. DOI: https://doi.org/10.1016/s0167-7012(99)00037-8

Broberg CA, Calder TJ and Orth K (2011).Vibrio parahaemolyticus cell biology and pathogenicity determinants. Microbes and infection / Institute Pasteur.;13(12-13): 992-1001.DOI: https://doi.org/10.1016/j.micinf.2011.06.013.

Chao G, Jiao X, Zhou X, Yang Z, Huang J, and Pan Z (2009). Serodiversity, pandemic O3:K6 clone, molecular typing, and antibiotic susceptibility of food borne and clinical Vibrio parahaemolyticus isolates in Jiangsu, China. Foodborne Pathogenic Disease.6(8): 1021-1028. DOI: https://doi.org/ $10.1089 /$ fpd.2009.0295

Clinical and Laboratory Standards Institute (CLSI) (2012). Performance standards for antimicrobial disk susceptibility tests; approved standard, $11^{\text {th }}$ ed (M02-A11). Clinical and Laboratory Standards Institute, Wayne, Pennsylvania. Available at: http://www.facm.ucl.ac.be/intranet/CLSI/CLSI$\underline{\mathrm{M} 100 \mathrm{~S} 22}$

Dalsgaard A, Forslund A, Sandvang D, Arntzen L and Keddy K (2001). Vibrio cholera O1 outbreak isolates in Mozambique and South Africa in 1998 are multiple-drug resistant, contain the STX element and the aadA2 gene located on class 1 integrons. Journal of Antimicrobial Chemotherapy, 48: 827-838. DOI: https://doi.org/10.1093/jac/48.6.827.

Deepanjali A, Sanath K and Karunasagar I (2005). Seasonal variation in abundance of total and pathogenic Vibrio parahaemolyticus bacteria in oysters along the Southwest coast of India. Applied and Environmental Microbiology, 71: 3575-3580. DOI: https://doi.org/10.1128/AEM.71.7.3575$\underline{3580.2005}$

DePaola A, Nordstrom JL, Bowers JC, Wells JG and Cook DW (2003). Seasonal Abundance of Total and Pathogenic V. parahaemolyticus in Alabama Oysters. Journal of Applied and Environmental Microbiology, 69 (3): 1521 -1526. DOI: https://doi.org/ 10.1128/AEM.69.3.1521-1526.2003

Egyptian Organization for Standardization and quality control (EOSQC) (2005). The Egyptian standard number 2005/3494. Available at: https://www.unescwa.org/egyptian-organization-standards-and-quality

Taviani E, Ceccarelli D, Lazaro N, Bani S, Cappuccinelli P, Colwell RR and Colombo MM (2008). Environmental Vibrio spp., isolated in Mozambique, contain a polymorphic group of integrative conjugative elements and class 1 integrons. FEMS Microbiology Ecology, 64: 45-55. DOI:https://doi.org/10.1111/j.1574-6941.2008.00455.x

Qadri F, Chowdhury NR, Takeda Y and Nair BG (2005). Vibrio parahaemolyticus-Seafood Safety and Associations with Higher Organisms. Oceans and Health: Pathogenes in the Marine Environment. Edited by Belkin and Colwell, Springer, New York, 2005. DOI: https://doi.org/10.1007/0387-23709-711

Fri J, Ndip RN, Njom HA and Clarke AM (2017). Occurrence of virulence genes associated with human pathogenic Vibrio isolated from two commercial Dusky Kob (Argyrosmus japonicus) farms and Kareiga Estuary in the Eastern Cape Province, South Africa. International Journal of Environmental Research Public Health, 14: 1111. DOI: https://doi.org/10.3390/ijerph14101111

Friesema IH, De Jong AE, Fitz James IA, Heck ME, Van den Kerkhof, JH and Notermans DW (2012). Outbreak of Salmonella thompson in the Netherlands since July 2012. Eurosurveillance, 17: 1-4. Available at: http://eurosurveillance.org/images/dynamic/EE/V17N43/art20303.pdf

Han H, Li F, Yan W, Guo Y, Li N, and Liu X (2015):. Temporal and spatial variation in the abundance of total and pathogeneic Vibrio parahaemolyticus in shellfish in China. PLoS One, 10(6): e0130302. DOI: https://doi.org/10.1371/journal.pone.0130302

Hasrimi AN, Budiharjo A and Jannah SN (2018). Detection of $t$ th and $t$ dh genes in Vibrio parahaemolyticus inhabiting farmed water ecosystem used for L. Vannamei aquaculture. Journal of Physics: Conference Series, 1025: 012058. DOI: https://doi.org/10.1088/1742-6596/1025/1/012058

Hemmat M, Ibrahim, Reham A, Amin1, Nesreen Z, Eleiwa and Hanan RM Ghanaym (2018). Vibrio species in fish and shell fish . Benha Veterinary Medical Journal, 34 (2): 246-254. DOI: https://doi.org/10.21608/bvmj.2018.29435

Hiyoshi H, Kodama T, Iida T, and Honda T (2010). Contribution of Vibrio parahaemolyticus virulence factors to cytotoxicity, enterotoxicity, and lethality in mice. Infection and Immunity, 78: 1772-1780. DOI: https://doi.org/10.1128/IAI.01051-09

Hubbard TP, Chao MC, Abel S, Blondel CJ, zur Wiesched PA, Zhoue X, Davis BM and Waldor MK (2016). Genetic analysis of Vibrio parahaemolyticus intestinal colonization, Proceedings of the National Academy of Sciences, 113 (22): 6283-6288. DOI: https://doi.org/ $10.1073 /$ pnas. 1601718113

Huss HH (1997). Control of indigenous pathogenic bacteria in seafood. Food Control, 8(2): 91-98. DOI:https://doi.org/10.1016/S0956-7135(96)00079$\underline{5}$

International Commission on Microbiological Specifications for Foods (ICMSF) (1996). Vibrio cholera. In: Microorganisms in Foods 5. Characteristics of Microbial Pathogens. London: Blackie Academic \& Professional, pp. 414-425. Available at: https://www.iso.org/organization/9260.html

International Organization for Standardization/technical specification (ISO/TS21872-1) (2007). Specifies a horizontal method for the detection of the two main pathogenic Vibrio species causing intestinal illness in humans: $V$. parahaemolyticus and $V$. cholera. Available at: https://www.iso.org/standard/38278.html

International Organization for Standardization/technical specification (ISO/TS21872-2) (2007). Specifies a horizontal method for the detection of the enteropathogeneic Vibrio species, causing illness in or via the intestinal tract, other than V. parahaemolyticus and $V$. cholera. Include $V$. fluvialis ,V. mimicus and V. vulnificus. Available at: https://www.iso.org/standard/38279.html

Iwahori J, Yamamoto A, Suzuki H, Yamamoto T, Tsutsui T and Motoyama K (2010). Quantitative risk assessment of Vibrio parahaemolyticus in finfish: a model of raw horse mackerel consumption in Japan. Risk Analysis, 30(12): 1817-1832. DOI: https://doi.org/10.1111/j.1539$\underline{6924.2010 .01444 . x}$.

Kim YB, Okuda J, Matsumoto C, Takahashi T, Hashimoto S and Nishibuchi M (1999). Identification of Vibrio parahaemolyticus Strains at the Species Level by PCR Targeted to the toxR Gene. Journal of Clinical Microbiology, 37 (4): 1173-1177. DOI: https://doi.org/10.1128/JCM.37.4.11731177.1999

Kishishita M, Matsuoka N, Kumagai K, Yamasaki S, Takeda Y and Nishibuchi M (1992). Sequence variation in the thermostable direct hemolysin related hemolysin (trh) gene of Vibrio parahaemolyticus. Applied and Environmental Microbiology, 58: 2449-2457. Available at: https://www.ncbi.nlm.nih.gov/pmc/articles/PMC195802/ 
Liao Y, Li Y, Wu S, Mou J, Xu Z and Cui R ( 2015). Risk Factors for Vibrio parahaemolyticus Infection in a Southern Coiastal Region of China. Food borne Pathogenic Disease, 12(11): 881-886. DOI: https://doi.org/10.1089/fpd.2015.1988

Rojas MVR, Mattè MH, Drorpa M, da Silva ML and Mattè GR (2011). Characterization of Vibrio parahaemolyticus isolated from Oysters and Mussels in SÃO PAULO, BRAZIL. Rev. Inst. Med. Trop. Sao Paulo. 53(4): 201-205. DOI:https://doi.org/10.1590/S0036-46652011000400005

Abdel-Azeem MW, Attaya A, Manal I, El-Barbary and Sultan S (2016). Isolation and molecular detection of pathogenic Vibrio species among economic fish from Red Sea in Egypt. British Microbiology Research Journal, 12(6): 1-8. DOI: https://doi.org/10.9734/BMRJ/2016/42016

Mustapha S, Mustapha EM and Nozha C (2013). Vibrio Alginolyticus: An Emerging Pathogen of Food borne Diseases. International Journal of Science and Technology, 2 (4). 302-309.

Osawa R, Okitsu T, Morozumi H and Yamai S (1996). Occurrence of urease-positive Vibrio parahaemolyticus in Kanagawa, Japan, with specific reference to presence of thermostable direct hemolysin (TDH) and the TDH-related hemolysin genes. Applied and Environmental Microbiology, 62:725-727. Available at" https://www.ncbi.nlm.nih.gov/pubmed/8593076

Pal D and Das N (2010). Isolation, identification and molecular characterization of Vibrio parahaemolyticus from fish samples in Kolkata; European Review for Medical and Pharmacological Sciences.14: 545-549. Available at: https://www.europeanreview.org/article/778

Raissy M, Rahimi E, Azargun R, Moumeni M, Rashedi M and Sohrabi HR (2015). Molecular detection of Vibrio spp. in fish and shrimp from the Persian Gulf. Journal of Food Biosciences and Technology, 5(2): 49-52. Available at: http://jfbt.srbiau.ac.ir/article_7003.html

Randall LP, Cooles SW, Osborn MK, Piddock LJV and Woodward MJ (2004). Antibiotic resistance genes, integrons and multiple antibiotic resistance in thirty-five serotypes of Salmonella enteric isolated from humans and animals in the UK. Journal of Antimicrobial Chemotherapy,53: 208-216. DOI: https://doi.org/10.1093/jac/dkh070.

Saad MS, Samir MM and Abd El Maksod HES (2015). Incidence of Vibrio species in fish with special emphasis on the effect of heat Treatments. Benha Veterinary Medical Journal, 29 (1): 38-44. Available at: http://www.bvmj.bu.edu.eg

Shirai H, Ito H, Hirayama T, Nakabayashi Y, Kumagai K, Takeda Y, and Nishibuchi M (1990). Molecular epidemiologic evidence for association of thermostable direct hemolysin (TDH) and TDH-related hemolysin of Vibrio parahaemolyticus with gastroenteritis. Infection and Immunity, 58: 3568-3573. Available at" https://pubmed.ncbi.nlm.nih.gov/2228229/

Su YC and Liu C (2017). Vibrio parahaemolyticus: a concern of seafood safety. Food Microbiology, 24(6): 549-558. DOI: https://doi.org/10.1016/j.fm.2007.01.005

Sujeewa AKW, Norrakiah AS and Laina M (2009). Prevalence of toxic genes of Vibrio parahaemolyticus in shrimps (Penaeus monodon) and culture environment. International Food Research Journal, 16: 89-95. Available at: http://www.ifrj.upm.edu.my/20IFRJ-2008-Sujeewa

Vongxay K, Pan Z, Zhang X, Wang S, Cheng S and Mei L (2008). Occurrence of pandemic clones of Vibrio parahaemolyticus isolates from seafood and clinical samples in a Chinese coastal province. Foodborne Pathogenic Disease, 5(2):127-134. DOI: https://doi.org/10.1089/fpd.2007.0045

Wang H, Tang X, Su Y-C, Chen J and Yan J (2017). Characterization of clinical Vibrio parahaemolyticus strains in Zhoushan, China, from 2013 to 2014. PLoS One, 12(7): e0180335. DOI: https://doi.org/10.1371/journal.pone.0180335

Wang R, Zhong Y, Gu X, Yuan J, Saeed A Fand and Wang S (2015). The pathogenesis, detection and prevention of Vibrio parahaemolyticus. Frontiers in Microbiology, 6: 144. DOI: https://doi.org/ 10.3389/fmicb.2015.00144

Wong HC, Lui SH, Wang TK, Lee CL, Chiou CS, Lui DP, Nishibuchi M and Lee BK (2000). Characterization of Vibrio parahaemolyticus O3:K6 from Asia. Applied and Environmental Microbiology, 66: 3981-3986. DOI: https://doi.org/10.1128/AEM.66.9.3981-3986.2000

Wu Y, Wen J, Ma Y, Ma X and Chen Y (2014). Epidemiology of food borne disease outbreaks caused by Vibrio parahaemolyticus, China, 2003-2008. Food Control, 46: 197-202. DOI: https://doi.org/10.1016/j.foodcont.2014.05.023

Yamaichi Y, Iida T, Park KS, Yamamoto K and Honda T (1999). Physical and genetic map of the geneome of Vibrio parahaemolyticus: Presence of two chromosomes in Vibrio species. Molecular Microbiology, 31: 1513-1521. DOI: https://doi.org/10.1046/j.1365-2958.1999.01296.X.

Yoon KS, Min KJ, Jung YJ, Kwon KY, Lee JK and Oh SW (2008). A model of the effect of temperature on the growth of pathogenic and nonpathogenic Vibrio parahaemolyticus isolated from oysters in Korea. Food Microbiology, 25(5): 635-641. DOI: https://doi.org/ 10.1016/j.fm.2008.04.007.

Yung BK, Jun O, Chiho M, Naoki T, Saouri H, Mitsuaki IN, Hashimoto S and Nishibuchi M (1999). Identification of Vibrio parahaemolyticus Strains at the Species Level by PCR Targeted to the toxR Gene. Journal of Clinical Microbiology, 37 (4): 1173-1177. Available at: https://www.ncbi.nlm.nih.gov/pmc/articles/PMC88669/

Zulkifli Y, Alitheen NB, Son R, Raha A R, Samuel L, Yeap SK and Nishibuchi M (2009). Random amplified polymorphic DNA-PCR and ERIC PCR analysis on Vibrio parahaemolyticus isolated from cockles in Padang, Indonesia. International Food Research Journal, 16: 141-150. 